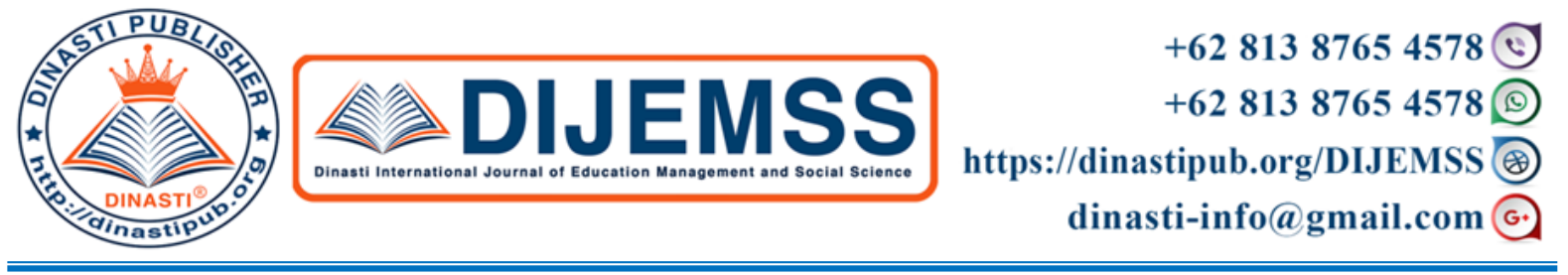

\title{
BUSINESS ETHICS AND GOOD CORPORATE GOVERNANCE IN RELEVANCE IMPLEMENTATION OF THE COMPANY'S SOCIAL RESPONSIBILITY
}

\section{Judiatin Rachmiarti Kusumah}

Mercu Buana University, Jakarta, Indonesia

ARTICLE INFORMATION

Received: $20^{\text {th }}$ May 2020

Revised: $27^{\text {th }}$ June 2020

Issued: $22^{\text {th }}$ August 2020

Corresponding author: first author

E-mail:

judiatin@gmail.com

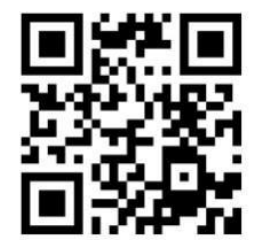

DOI:10.31933/DIJEMSS
Abstract: The challenges for companies are getting bigger today. CSR is used as a guideline for corporate strategy to take the interests of all stakeholders into account. The application of CSR has to do with how the company is well managed and managed (GCG). The implementation of GCG has a positive effect on the business environment of a company and has a positive effect on the company as investors increasingly trust the company. CSR develops because the long-term sustainability of the company is more important than just profitability. Companies have social and ecological responsibility for ethical behavior, which is referred to as corporate social responsibility (CSR) or corporate citizenship. Corporate Social Responsibility (CSR) is a company's commitment to the conduct of its business. It aims not only to increase the company's financial profit, but also to build a sustainable socioeconomy. It can be concluded that the fundamental aspect of implementing CSR for the company is a form of the company's commitment to the well-being of employees and their families, the surrounding community (local) and in particular the entire community and that the implementation takes place in a sustainable manner. This paper is intended to provide an overview of the implementation of corporate social responsibility with its relevance to business ethics and good corporate governance in Indonesia. The research method used is a library and observation method based on the author's experience in dealing with PT XYZ Raya, one of the national companies for paints and chemicals, as a supplier of various types of colors

Keywords: Business ethics, good corporate governance, corporate social responsibility, sustainable commitment, corporate sustainability. 


\section{INTRODUCTION}

The term corporate governance means "corporate management" or "corporate governance". The loss that occurs when limited resources are used in the corporate environment due to the economic activities of companies that are not well managed can lead to a negative public reaction to the existence of the company. The company was founded not only to generate profits for shareholders, but also to take into account the interests of the community and the environment around the company in which it operates.

The concept of corporate social responsibility (CSR) is important for companies in order to maintain good relationships with the environment and society.

\section{LITERATURE REVIEW}

\section{A. Definition of CSR (Corporate Social Responsibility) in the opinion of the expert}

There are two types of terms in the CSR concept, namely a broad understanding and a narrow understanding. CSR in the broadest sense refers to the goal of sustainable economic activity (sustainable economic activity) that is not only related to social responsibility including accountability in the form of corporate responsibility and contribution to the interests of the surrounding community (local) and in particular the general public and the general public Nation in the international world.

CSR in the narrower sense is understood from several expert opinions, including:

1. CSR is a collaboration between a company and all stakeholders who interact directly or indirectly with the company to ensure the existence and survival of the company (Widjaja \& Yeremia, 2008). This understanding is the same as responsibility for the social community and the environment in the form of a company's commitment to play an active role in sustainable economic growth, with the aim of improving the quality of life and the environment that the company, the local community and benefit society in general.

2. Kotler \& Nance (2005) defines the company's commitment to improving the wellbeing of the surrounding community through guidelines for business practices and the contribution of corporate resources.

3. The World Business Council for Sustainable Development defines CSR as an obligation for companies to contribute to sustainable economic development by paying attention to employees together with their families, the surrounding communities and the general public in order to improve quality of life and to improve.

4. The Commission of the European Communities defines CSR as a business concept that makes voluntary contributions to achieving a better society and the environment.

5. Asian CSR, CSR in the form of a company's obligation to work continuously on the basis of economic, social and ecological principles while at the same time maintaining the balance of the various interests of all parties involved.

According to the above definitions, corporate social responsibility (CSR) is simply a concept of a company's activities in assuming its responsibility towards the social community and the environment in which the company operates or operates. For example, by building public facilities, protecting the environment, providing scholarship programs for disadvantaged 
children, and providing financial support for the common good in general and the surrounding community in particular.

In Indonesia, the definition of CSR in Law No. 40 of 2007 on Limited Liability Companies (UUPT) is Article 1 (3), which provides:

"Social and environmental responsibility is the company's obligation to participate in sustainable economic development to improve the quality of life and the environment, which benefits both the company itself and the local community and society in general. "

The form of corporate responsibility for stakeholders comprises three definitions:

a. The company strives to play an active role and improve the quality of life between the company and its employees and their families, the local community and the general public. Together they play a role in sustainable economic development.

b. The company strives to act ethically, act legally, and play an active role in improving the economy. The aim is to improve the quality of life of employees and their families, communities or local communities.

c. Take social measures, pay attention to the environment that goes beyond the statutory or prescribed limits

CSR (Corporate Social Responsibility) is very closely linked to sustainable development (ie sustainable development), in which companies must base their activities on decisions that not only have financial advantages for the interests of the company itself and all parts involved, but also also consider the environment for the outside world, especially for the environment.

\section{Good and real CSR properties}

Here are some of the features and characteristics of CSR consisting of :

- CSR must reflect the principles of good corporate governance, namely transparency and accountability.

- CSR must be based on the interests of the stakeholders inside and outside the company.

- CSR must be able to have long-term effects on the company and society

- CSR must carry out activities that support the applicable laws and regulations.

- The CSR implementation is based on ISO 26000.

\section{Corporate Social Responsibility (CSR) function}

The function of CSR (Corporate Social Responsibility) in general is the perception of the company's responsibility towards those involved or directly or indirectly affected by all of the company's activities. On this basis, the company is responsible for paying more attention to all Phaks involved.

The following describes the benefits or features of CSR for the business, including the following:

\section{Social operating license}


Society is one of the factors that move a company or not. With CSR, the surrounding community will benefit from the existence of a business in their area, of course the community will feel benefited and will feel like the "owner" of the business over time. In such a situation, the company can carry out activities and business activities in the region.

\section{Good relationships with Stakehoder}

The implementation of the CSR program (Corporate Social Responsibility) can establish close communication between the company and its stakeholders and strengthen the trust of the stakeholders in the company.

\section{Eliminate company business risks}

CSR (Corporate Social Responsibility) creates a good relationship between the company and the parties involved so that it can be easily dealt with in the event of unrest and the costs of risk transfer are redirected to something that is beneficial for the community or the company.

\section{Increase the spirit and productivity of the employees}

A large company's contribution to stakeholders, society, and the environment can improve the company's reputation for the better. This condition can increase the pride of the company's employees and improve employee morale and productivity.

\section{Offer market opportunities}

Costs invested by companies in corporate social responsibility (CSR) programs can open up opportunities to win a larger market. In addition, this can have an impact on customer loyalty to the company and help companies tap new market shares. CSR programs also have a positive impact on the company's name and brand, making the company better known and admired by the general public.

\section{Expand access to resources}

Corporate Social Responsibility (CSR) can improve the existence of the company in the eyes of society and can become a means for companies to obtain the necessary resources.

\section{Improve the relationship with the supervisory authorities}

Corporate social responsibility can help relieve the burden on the government as a regulator in building the well-being of society and the environment.

\section{Reduce costs}

CSR programs in the form of applying the concept of recycling corporate waste can save company costs, so that corporate waste is controlled and also have an impact on reducing production costs.

\section{Chance of an award}

Corporate social responsibility (CSR) programs, in the form of corporate contributions aimed at the general public and the environment, offer companies the opportunity to receive an award, and this will give the company pride.

\section{Advantages of CSR (Corporate Social Responsibility)}

\section{Community benefits}

- Increased common good and ecological sustainability

- Scholarship programs for disadvantaged children in the area.

- Increased maintenance of public facilities.

- Building a village and its facilities is very useful for many people in the company 
The main advantage of CSR is that the community can better develop themselves and their businesses so that their wellbeing can be achieved.

\section{Advantages for the company}

- The company's image is increasing

Companies that actively engage in activities that are good for the community will be better known to consumers.

- Strengthening corporate brands in the eyes of the public and consumers

By providing training on the company's product knowledge and selling products free of charge, consumers' awareness of the existence of the company's products is raised, so that the company's brand automatically grows.

- Development of cooperation with stakeholders

Cooperation between businesses and stakeholders, local governments, the public, and universities across the enterprise in implementing CSR programs can improve the fabric of good relationships between them.

- Differentiate the company from its competitors

With CSR, the company has the opportunity to highlight its competitive advantage to differentiate its position from competitors that offer the same product or service.

- Providing innovation and learning for the company

The implementation of CSR, which is programmed continuously and regularly, will trigger innovations from all components of the company, which in turn can improve the role and position of the company in global business.

\section{B. Good corporate governance}

According to experts, the definition of good corporate governance (GCG) is as follows:

1. According to Wahyudi Prakarsa (2007: 120), good corporate governance is an administrative mechanism for regulating the relationships between company management, commissioners, directors, shareholders and all other interest groups. The relationship is to embody various rules of the game and the incentive system as a framework that is required to determine corporate goals and ways to achieve and achieve those goals, while monitoring the resulting performance.

2. According to Sukrisno Agoes (2011: 101): is a system that manages and regulates the relationships and roles of the Board of Commissioners, the role of the Board of Directors, shareholders and other stakeholders. Good corporate governance is a transparent process for determining corporate goals, performance and performance evaluation.

According to the two experts, the definition of good corporate governance (GCG), as defined by the UK Cadbury Committee in Sukrisno Agoes (2011: 101), provides an understanding that GCG is good corporate governance, which is the relationship between Shareholders and management (managers) of the company regulates For creditors, the government, employees and other internal and external stakeholders, this rule applies to all of their rights and 
obligations. In other words, it is a system that controls and controls the activities of the company. "

From some of the meanings mentioned above, it can be interpreted that good corporate governance (GCG) is good corporate governance, which is based on the principle of the participation of all stakeholder components in accordance with the law and the rule of law and is carried out with full transparency, responsiveness, consensus orientation, fairness and fairness becomes fairness, efficiency and effectiveness, accountability and strategic vision in the management and control of a company.

\section{The concept of good corporate governance}

\begin{tabular}{|c|c|}
\hline Contain & Organization (business, social affair, government) \\
\hline Model & $\begin{array}{l}\text { A system, a process and a set of rules, including the } \\
\text { principles and values that underpin sound business } \\
\text { practices }\end{array}$ \\
\hline Aim & $\begin{array}{l}\text { Improve organizational performance } \\
\text { - }\end{array}$ \\
- Preate added value for all stakeholders \\
management errors when an error occurs that can be \\
fixed quickly \\
- So that the stakeholders are not disadvantaged
\end{tabular}

\section{Principles of good corporate governance}

According to the National Committee on Governance (2006) in Sukrisno Agoes (2009: 104), the five principles of GCG include:

\section{- Transparency}

All company activities are managed transparently for all those involved in the company. The activities mentioned here include honesty in the preparation of annual reports, the lack of manipulation, information in the decision-making process and the disclosure of information that is considered important and relevant for the company and the shareholders.

\section{- Accountability}

The management must create a clear job description for all employees and give assertiveness to all functions of the individual areas, so that everything is clear in every company policy 
between the rights and obligations, responsibilities, functions and powers. The positive effect is that corporate governance is implemented effectively and efficiently.

- Fairness

When performing its business, the company always ensures equality or fair treatment based on agreements and applicable laws and regulations.

- Responsibility

The systematic of the institution and the implementation process must be carried out within a clear time limit, and the service is intended for everyone involved. The company must ensure compliance with all standards applicable in the local community, give appreciation and always react proactively to changes and social developments in the community.

- Independence

The company must be managed independently so that not every component of the company dominates each other and no party can intervene with the following guidelines:

a) All elements of the company must avoid the rule of a party that is not influenced by certain interests, influences or pressures

b) Each component of the company must fulfill its functions and duties in accordance with the established basic rules and regulations.

\section{GOALS Good corporate governance}

According to Siswanto Sutojo (2008: 5), the goals of good corporate governance have five main goals:

a) Aprovides protection for the rights and interests of shareholders;

b) Protection of the rights and interests of other interest groups;

c) Increase the value of shares and companies;

d) Improving the performance of the Board of Directors and the Executive Board;

e) Improve the quality of the relationship between the Board of Commissioners and senior management.

To achieve its goals, all activities are carried out through the implementation of an internal control system, which includes:

a) Structured control consists of:

1. Integrity, ethical values and employee competence

2. Management philosophy and style

3. Balance between responsibility and rights

4. Personnel development

5. Instructions from directors

b) business risk assessment and management;

c) Comprehensive control in every unit, every aspect and every level;

d) Obedience in implementing regulations, reporting processes and accountability

e) Support of the internal audit in the internal monitoring system.

\section{GCG BENEFITS}

Tjager et al. (2003) there are five reasons why the use of GCG is useful, namely: 
1. Based on a survey by McKinsey \& Company, it can be seen that all companies in Asia that implement GCG are increasingly gaining trust among institutional investors.

2. There is an indication of the relationship between the financial crisis and the ongoing Asian crisis with weak management in the company.

3. The internationalization of markets, liberal financial markets and all capital markets require companies to implement GCG.

4. GCG is not a solution to get out of the crisis, but the GCG system can be the basis for the development of a new value system that is more in line with the business foundation that has now undergone changes.

5. Implementing GCG can increase the value of the company in the eyes of the public or consumers.

\section{RESEARCH METHOD}

In writing this paper, the author obtains data used in the paper using data collection methods in the form of literature studies, collecting data from multiple books, journals, and searching and collecting data over the Internet and annual reports. This method aims to provide the author's ideas and opinions to solve problems or case studies that occur in the present but are still focused on the actual problem

\section{RESULT AND DISCUSSION}

In order to implement good CSR, the four principles of good corporate governance, namely fairness, transparency, accountability and responsibility, must be reconciled and combined with the interests of shareholders and stakeholders. CSR not only focuses on achieving results alone, but must also focus on the performance process.

\section{Basic understanding of CSR for the company}

Understanding CSR generally revolves around three main points :

- Voluntarily, a company has the flexibility to decide whether it wants to help overcome social and ecological problems or not

- The company acts as a profit-making institution, on the other hand, the company has also provided part of the profit for philanthropy (philanthropy) to play a social role and repair environmental damage through exploration and exploitation.

- It is the company's duty to help solve the humanitarian crisis and increasing environmental problems.

CSR is evolving to change from the form of the charity principle to the stewardship principle (Anne, 2005). Charity principle, ie the community has a moral obligation to help disadvantaged people. While the stewardship principle is to place the company's position as ruler of a large resource where the use of those resources has an impact on society. The company is therefore responsible for making good use of these resources and can benefit the interests of shareholders and society in general. 


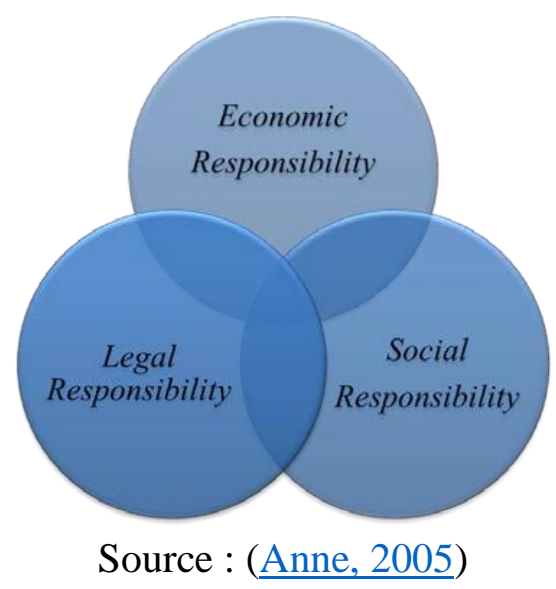

Therefore, a company is responsible for managing its economic responsibility towards shareholders and for complying with and enforcing applicable laws and social responsibilities towards stakeholders.

\section{The relationship between corporate social responsibility and good corporate governance}

In accordance with the principles of good corporate governance (GCG), a common thread can be drawn in the relationship between good corporate governance (GCG) and corporate social responsibility (CSR), namely the principle of responsibility.

The company can see that the operational activities have external effects that must be borne by the stakeholders. The company bears the responsibility or is responsible for considering the interests and added value for its stakeholders.

Stakeholders, especially investors, value CSR practices by using CSR programs as analytical material to assess the potential for business continuity and profitability. Pambudi (2006) explains that stakeholders recognize that if a company does not implement a CSR program, the company does not live up to its social responsibility and have doubts about the sustainability of its business. The results of previous studies in several industrialized countries show that public trust in companies that implement CSR and CSR programs is increasing and has a positive impact on the company's financial performance.

\section{CSR as GCG implementation at PT XYZ Raya Paint Company}

PT XYZ Raya is a national company in Indonesia located in the city of Tangerang. It is a manufacturing company that makes paints and chemicals for buildings. This company is one of the paint manufacturers that takes great care of the environment. Indeed, one of the company's missions is environmental, namely: Environment - its mission is to manufacture environmentally friendly products during the production process by complying with the standards required to fulfill environmentally friendly processes.

With the support of an experienced research and development team, PT XYZ Raya manufactures many types of lacquer products, including: wood lacquer systems for wood and rattan furniture, wood care for private households, architectural paints, paint protection for iron, floor paints, leak-proof paint and other industrial coatings. All paint products manufactured by PT XYZ Raya are geared towards environmentally friendly paint products, as the motto of this environmentally friendly company is a commitment to environmental 
protection. The company's commitment to environmental protection and environmental protection through the production of environmentally friendly paint products is an example of the implementation of one of the principles of good corporate governance by management and all of its stakeholders, namely responsibility. The company with its business ethics is committed to maintaining environmental sustainability, which benefits all employees of the company and the surrounding community.

As a national company, PT XYZ Raya is committed to supporting Indonesia's development with paint products made by the country's children. In order to strengthen support and cooperation with the government (regulatory authority), the company uses Corporate Social Responsibility (CSR) to reduce the burden on the government as a regulatory authority for the good of the environment and its people.

Various CSR programs implemented by PT XYZ Raya, primarily focused on supporting government programs and more on environmental protection and maintenance efforts with the support of using the company's environmentally friendly products. Among the implemented CSR programs :

- Active support of government programs in the development of "green building" through the development and maintenance of the archipelago architecture, which is confirmed by several awards such as the Green Building Award

- In collaboration with the Ministry of Tourism and Industry, a national archipelago architectural competition is held each year to support and develop the talents of Indonesian national architecture in Indonesia.

- Implement CSR by supporting the \$1 million house program with free bricklayer training for developers building affordable and subsidized houses

- Through a CSR program in collaboration with the DKI Jakarta Provincial Government that provides training and professional certification in painting for daily workers outside the DKI Provincial Government

- CSR for painting applicator in Covid-19 situation.

Some examples of the implementation of CSR programs carried out by PT XYZ Raya are a description of the implementation of GCG by the company, in particular the implementation of the principle of responsibility. The CSR program shows that the company is not only business-oriented or looking for financial benefits for the interests of the company, but also thinks about the interests of the outside world, especially the environment. The company has a sense of responsibility towards the social environment and the environment in which the company operates or is located.

PT XYZ Raya is aware that the economic activities carried out by the company according to the application of the principles of business ethics are likely to be beneficial not only for the company itself, but also for society. This is a form of concern and responsibility of the business world towards the community, the environment (as a form of corporate social responsibility) and the form of their contribution to sustainable economic development (sustainable growth) with the aim of improving the quality of life of employees and their families, of local communities and the entire community. .

With the implementation of CSR as the implementation of the GCG basic responsibility of the company, this has a positive effect on the company, including: The 
image and the brand of the company become better and publicly known, so that the business opportunities in the market for PT XYZ Raya are greater are and also have a positive impact on the financial development of the company.

\section{CONCLUSION AND SUGGESTION}

\section{Conclusion}

The implementation of corporate social responsibility (CSR) is a form of implementation of the concept of good corporate governance or GCG. Because business people have a responsibility to society and the environment, the company should always be able to act as a good citizen, which is a requirement for good business ethics.

The implementation of Corporate Social Responsibility (CSR) as the implementation of the concept of Good Corporate Governance (GCG) has a positive effect on the company's image and brand as well as on the company's financial development.

\section{Suggestion}

The manifestation of GCG implementation by the company and all business people correctly, namely through unrestricted and continuous implementation of CSR, so that the benefits for the company, employees and their families, the community close to the company and society in general are felt .

\section{REFERENCES}

Anne, L. T. (2005). Business and Society : Stake Holders, Ethics, Public Policy. International, 11 Ed., Mc Graw Hill

Cadbury report. (1992). The Report of the Cadbury Committee on Financial Aspects of Corporate Governance. The Code of Best Practise, Cadbury-Schweppes.

Kim, K.A., Nofsinger, J.R., \& Mohr, D.J. (2009). Corporate Governance. $3^{\text {rd }}$ Edition, Pearson.

Kotler, P., \& Nance, L. (2005). Corporate Social Responsibility : Doing The Most Good for Your Company and Your Cause. John Wiley \& Sons Inc.

Laila, Noor. (2011). Analisis Pengaruh Good Corporate Governance Terhadap Nilai Perusahaan. Diponegoro Journal of Accounting Vol. 3 No. 2.

Pieris, John \& Wiryawan, N J. 2007. Etika Bisnis dan Good Corporatr Governance. Jakarta: Pelangi Cendekia.

Prakarsa, Wahyudi. (2007). Corporate Governance : Suatu Keniscayaan. Jurnal Reformasi Ekonomi, Vol. 1 No. 2 Oktober.

Restuningdiah. (2010). Mekanisme GCG dan Pengungkapan Tanggung Jawab Sosial terhadap Koefisien Respon Laba. Jurnal Keuangan dan Perbankan, Vol. 14, No 3 Sepetember 2010, pp. 377-390.

Saviera, Lesly. (2012). Corporate Social Responsibility (CSR) sebagai Penerapan Prinsip Good Corporate Governance (GCG) Terkait dengan Sustainability Development. Tesis. Program Studi Magister Ilmu Hukum USU.

Sukrisno, Agoes. (2011). Etika Bisnis dan Profesi. Jakarta, Salemba Empat.

Tjager. (2003). Corporate Governance : Tantangan dan Kesempatan bagi Komunitas Bisnis Indonesia. Jakarta. 
Yeremia, Ardi P., Gunawan, Widjaja. (2008). Risiko Hukum dan Bisnis Perusahaan Tanpa CSR. Jakarta, Forum Sahabat.

Undang-Undang No 40 Tahun 2007 Tentang Perseroan Terbatas. 